\title{
PENGARUH TINGKAT FINANCIAL LITERACY DAN FAKTOR SOSIODEMOGRAFI TERHADAP PERILAKU KEPUTUSAN INVESTASI INDIVIDU
}

\author{
Ni Made Dwiyana Rasuma Putri ${ }^{(1)}$ \\ Henny Rahyuda ${ }^{(2)}$ \\ ${ }^{(1)(2)}$ Fakultas Ekonomi dan Bisnis Universitas Udayana, Bali, Indonesia \\ e-mail: rasumaputri@gmail.com
}

\begin{abstract}
ABSTRAK
Tujuan dari penelitian ini adalah untuk mengetahui pengaruh tingkat financial literacy dan faktor sosiodemografi terhadap perilaku investasi individu. Responden adalah pegawai yang belum menikah di Denpasar dengan sampel 83 orang. Penentuan sampel menggunakan non probability sampling dengan pendekatan accidental sampling. Data dianalisis dengan menggunakan Analisis Regresi Linier Berganda. Hasil penelitian ini menunjukkan bahwa tingkat financial literacy berpengaruh positif terhadap perilaku keputusan investasi perorangan, sedangkan perbedaan pengaruh antara pria dan wanita terhadap perilaku keputusan investasi individu dan pendapatan berpengaruh negatif terhadap perilaku keputusan investasi individual. Berdasarkan hasil statistik data variabel financial literacy memiliki pengaruh terbesar dalam menentukan perilaku keputusan investasi individu dibandingkan dengan faktor sosiodemografi. Ini menjelaskan bahwa pengetahuan seseorang tentang mengelola keuangan pribadinya merupakan faktor kunci dalam menentukan keputusan investasi.
\end{abstract}

Kata kunci: financial literacy, faktor sosiodemografi, gender, pendapatan, dan keputusan investasi

\section{ABSTRACT}

The purpose of this study is to explain the influence level of financial literacy and sociodemographic factors on behavior of individual investment. Respondents are unmarried employees in Denpasar with a sample of 83 peoples. Determination of sample using nonprobability sampling with accidental sampling approach.Data were analyzed by using Multiple Linear Regression Analysis. The results of this study indicate that the level of financial literacy has a positive effect on the behavior of individual investment decisions, whereas the differences in influence between men and women on the behavior of individual investment decisions and income negatively affect the behavior of individual investment decisions. Based on the results of statistical data financial literacy variables have the greatest influence in determining the behavior of individual investment decisions compared with sociodemographic factors. This explains that a person's knowledge of managing his personal finances is a key factor in determining an investment decision.

Keywords: financial literacy, sociodemographic factors, gender, income, and investment decisions 


\section{PENDAHULUAN}

Sejak jaman dahulu hingga sekarang setiap individu mempunyai tujuan hidup yang ingin dicapai. Bentuk dari tujuan hidup pun berbeda-beda pada setiap individu, namun pada dasarnya individu ingin hidupnya bahagia. Bahagia dalam hal ini dapat diartikan ketika inidividu telah sukses mencapai apa yang diinginkannya. Indikasi kesuksesan individu dapat diukur dari berbagai hal misalnya harta yang berhasil dikumpulkan, jenjang karir yang dicapai, tingkat pendidikan yang dilalui dan kontribusi terhadap kehidupan lainnya khusus pada bidang keuangan individu dikatakan sukses mencapai kebahagiaannya jika sudah mencapai kebebasan finansial (financial freedom), maksudnya adalah uang itu sudah tidak lagi dijadikan sebagai tujun kehidupan. Semua aktivitas dan keputusan kehidupan sudah tidak lagi semata-mata ditujukan untuk uang, namun uang dipandang sebagai serana mencapai tujuan yang lebih hakiki. Uang tidak lagi mengendalikan kehidupan individu, namun individulah yang mengendalikan uang tersebut.

Sikap konsumerisme yang menjadi kebiasaan saat ini membuat masyarakat kurang memiliki budaya menabung seperti misalnya berinvestasi. Masih banyak masyarakat yang belum menyadari pentingnya mempunyai manajemen keuangan di dalam kehidupan pribadinya karena masyarakat masih beranggapan bahwa perencanaan investasi keuangan pribadi hanya dilakukan oleh masyarakat yang memiliki pendapatan tinggi saja. Namun di sisi lain, masih terdapat juga individu yang memiliki pendapatan tinggi tetapi tidak mempunyai perencanaan investasi terhadap keuangan pribadinya (Pritazahara, 2015). Menurut Masassya (2006) 
menyatakan bahwa kebanyakan pengalokasian dana ditujukan pada beberapa hal yaitu, investasi, tabungan dan konsumsi. Diantara tiga hal tersebut, jenis pengalokasian yang paling memberikan manfaat dimasa depan adalah investasi. Perencanaan investasi pada keuangan pribadi merupakan hal yang penting, karena hal tersebut merupakan proses belajar mandiri untuk mengatur keuangan di masa sekarang dan masa yang akan datang (Pritazahara, 2015).

Investasi merupakan pengorbanan yang dilakukan pada saat sekarang dengan tujuan untuk mendapatkan manfaat yang lebih besar di masa yang akan datang (Haming dan Basalamah, 2010). Menurut Setiawan et al., (2016) budaya investasi merupakan satu hal yang menjadi syarat penting formasi pemodalan dan pertumbuhan ekonomi dalam masyarakat sebuah negara yang terdiri dari kumpulan perilaku, persepsi dan niat dari individu dan institusi untuk menempatkan simpanannya di berbagai aset keuangannya.salah satu faktor yang dibutuhkan untuk melakukan sebuah investasi adalah modal atau dana. Sumber dana dapat berasal dari pinjaman atau dana pribadi. Bagi investor individu dengan modal sendiri berarti menyisihkan sebagian penghasilannya. Hal tersebut tidak mudah untuk dilakukan karena banyaknya godaan untuk berperilaku konsumtif, inilah yang harus disadari bahwa seseorang itu harus memiliki pengetahuan keuangan yang memadai agar penghasilan yang diperoleh tidak hanya digunakan untuk konsumsi melainkan untuk berinvestasi yang bermanfaat di masa depan.

Ketika seseorang individu akan merencanakan untuk sebuah investasi, maka individu tersebut harus memiliki pengetahuan keuangan (financial literacy) yang baik agar keputusan keuangannya memiliki arah yang jelas. Financial 
literacy merupakan kebutuhan dasar bagi setiap orang agar terhindar dari masalah keuangan. Financial literacy menjadi hal yang tidak terpisahkan dalam kehidupan individu karena financial literacy merupakan sesuatu yang berguna dalam membuat keputusan keuangan. Individu dengan kemampuan financial literacy yang baik dapat juga dijadikan sebagai pertimbangan individu dalam pengambilan keputusan keuangan maupun perencanaan investasi namun apabila individu tidak memiliki financial literacy yang baik akan mengakibatkan terjadinya kesalahan dalam pengelolaan keuangan, kurangnya perencanaan terhadap simpanan masa depan dan kurangnya kesejahteraan hidup seseorang tersebut. Financial literacy dapat diartikan sebagai pengalaman setiap individu dalam mengelola keuangannya, dalam pengelolaan keuangan setiap inidividu mempunyai pengalaman yang berbeda seperti dalam merencanakan investasi, dana pensiun, asuransi dan kredit. Financial literacy merupakan bagian dari pembelajaran dalam mengelola keuangan maupun perencanaan investasi sehingga dalam membuat keputusan keuangan setiap hari dapat lebih terarah dan lebih bijaksana.

Financial literacy merupakan pemahaman umum terkait pengeloaan dan sikap mengenai keuangan. Financial literacy dapat diartikan sebagai pengetahuan keuangan dengan tujuan mencapai kesejahteraan (Lusardi dan Mitchell, 2007). Menurut Robb dan Woodyard(2011) financial literacy yang cukup akan memberikan pengaruh positif terhadap perilaku keuangan seseorang, seperti mengatur atau mengalokasikan keuangannya dengan tepat. Menurut PISA (2012) aspek-aspek yang terdapat dalam financial literacy yaitu uang dan transaksi, perencanaan dan pengelolaan keuangan, risiko dan keuntungan. Kemampuan- 
kemampuan tersebut menjadi aspek yang penting dalam penilaian untuk mengetahui kemampuan financial literacy seseorang. Banyak hal yang dapat mempengaruhi keempat aspek financial literacy tersebut.

Menurut Anggota Dewan Komisioner Otoritas Jasa Keuangan (OJK), Kusumaningtuti S. Soetiono dalam wawancaranya dengan Metro TV (2016) menyatakan bahwa literasi keuangan memiliki tiga komponen, yaitu pengetahuan, keterampilan, dan kepercayaan. Berdasarkan hasil penelitian OJK pada tahun 2013 terkait hal financial literacy, Indonesia masih sangat rendah yaitu sebesar 21,8\% dibandingkan dengan negara lain seperti Malaysia misalnya sebesar $80 \%$ dan Australia sebesar 99\%. Masyarakat dapat dikatakan memiliki financial literacy yang tinggi apabila sudah bisa menghargai uang, mengelola perencanaan keuangannya dan sudah bisa merencanakan keuangannya untuk masa depan yang menyebabkan masyarakat Indonesia masih kurang pengetahuannya terhadap financial literacy adalah masih kurangnya pengetahuan dan pencarian informasi mengenai tabungan atau investasi pada lembaga keuangan apakah itu bank atau asuransi dan kurang pahamnya mengenai manfaat tabungan atau asuransi tersebut. Banyak masyarakat yang kurang memiliki kecakapan finansial baik berupa pengetahuan dasar maupun yang lebih kompleks. Yulianti dan silvy (2013) menyatakan bahwa pengetahuan keuangan dan pengalaman keuangan berpengaruh terhadap perilaku perencanaan investasi keuangan keluarga. Sikap pengelola keuangan memoderasi dan memperkuat pengaruh pengetahuan keuangan dan tidak memoderasi pengalaman keuangan terhadap perilaku perencanaan investasi keuangan keluarga. 
Menurut Lusardi (2008) mengemukakan bahwa rendahnya pengetahuan keuangan berpengaruh terhadap perencanaan keuangan masa depan, sedangkan ketidaktahuan tentang konsep dasar keuangan dapat berhubungan dengan rendahnya perencanaan investasi. Hilgert, Hogart, Beverly (2003) menyatakan bahwa mengetahui dan memanfaatkan kredit, tabungan, dan investasi digolongkan memiliki pengetahuan keuangan dan pengalaman keuangan, sehingga peningkatan pengetahuan dan pengalaman keuangan dapat memperbaiki pengelolaan keuangan.

Teori lain juga dikemukakan oleh Sarah (2009) bahwa pengalaman keuangan adalah kemampuan untuk membuat pertimbangan atau pengambilan keputusan investasi dalam menentukan perencanaan dan pengelolaan investasi untuk mengetahui kegunaan manajemen keuangan untuk saat ini dan di masa yang akan datang.

Menurut Xiao et al., (2006) selain financial literacy ada faktor lain yang mempengaruhi keputusan investasi individu yaitu faktor sosiodemografi. Berdasarkan perilaku keuangan dilihat dari pengambilan keputusan investasi individu dengan membandingkan keadaan sosial demografi dilihat dari status pekerjaan (seseorang yang bekerja dengan yang belum bekerja). Sosial demografi merupakan ilmu yang mempelajari penduduk (suatu wilayah) terutama mengenai jumlah, struktur (komposisi penduduk) dan perkembangannya (perubahannya) dari waktu ke waktu. Variabel demografi termasuk status pekerjaan, status perkawinan, pendapatan, jenis pekerjaan, usia, jenis kelamin, pengalaman 
pekerjaan, dan tingkat pendidikan. Menurut Robb dan Woodyard, (2011) banyak program keuangan yang ditargetkan pada keadaan sosial demografi.

Menurut Hayhoe et al., (2000) perbedaan gender berpengaruh signifikan terhadap keputusan investasi. Perempuan lebih mungkin untuk melaporkan penggunaan praktik keuangan yang baik tetapi cenderung memiliki skor lebih rendah terhadap pengukuran pengetahuan keuangan (financial literacy) daripada laki-laki. Chen dan Volpe (2002) juga meneliti bahwa wanita kurang percaya diri dan kurang tertarik untuk belajar tentang pengetahuan keuangan (financial literacy) dibandingkan dengan laki-laki.

Menurut John et al., (2009) terdapat hubungan yang positif antara pendapatan (income) dengan perilaku manajemen keuangan yang bertanggung jawab. Artinya semakin baik pendapatan maka semakin baik dan bertanggung jawab perilaku keuangannya. Hasil penelitian ini didukung oleh teori prespektif perilaku keuangan dalam pengambil keputusan keuangan yang adaptif berarti bahwa sifat keputusan dan lingkungan di mana itu membuat pengaruh jenis proses yang digunakan. Semakin baik keadaan sosial demografi seseorang akan berpengaruh terhadap jenis proses pengambilan keputusan investasi yang digunakan kearah yang baik. Menurut Xiao et al., (2006) menyatakan bahwa umur dan status pekerjaan memiliki hubungan yang signifikan dengan kemampuan financial literacy, artinya semakin tinggi umur yang dimiliki seseorang dan semakin aman status pekerjaan seseorang maka semakin baik pemahamannya terhadap financial literacy dan semakin baik dalam pengambilan keputusan investasi. 
Permasalahan dalam penelitian ini adalah masih kurangnya pengetahuan masyarakat di Indonesia mengenai financial literacy fenomena ini didukung oleh penelitian yang dilakukan oleh OJK (2013) dimana masyarakat masih belum banyak mengetahui informasi mengenai tabungan atau investasi yang menyebabkan pola konsumsi masyarakat meningkat. Ketika pola konsumsi berlebihan maka akan berdampak pada timbulnya hutang atas konsumsi tersebut. Sangat penting bagi seseorang untuk paham dalam pengelolaan keuangan pribadinya untuk kesejahteraan di masa depan. Fenomena ini menandakan bahwa masyarakat seharusnya membutuhkan investasi untuk mempersiapkan masa depannya agar terhindar dari masalah keuangan. Maka dari itu penelitian ini difokuskan untuk meneliti bagaiman financial literacy dan faktor sosiodemografi dapat mempengaruhi keputusan invetasi individu.

Penelitian ini merupakan penelitian replikasi yang dilakukan oleh Pritazahara (2015) yang meneliti tentang keputusan investasi pada karyawan yang belum menikah. Penelitian ini juga mengacu pada penelitian yang dilakukan oleh Aminatuzzahra (2014) dan Setiawan et al., (2016) yang meneliti tentang bagaimana faktor sosiodemografi dan pengetahuan keuangan mempengaruhi keputusan invetasi individu.

Penelitian ini dilakukan pada karyawan di Kota Denpasar dengan status belum menikah (single). Adapun dasar pemilihan karyawan belum menikah (single) sebagai responden penelitian dalam keputusan investasi individu adalah menurut Pritazahara (2015) dikarenakan karyawan yang belum menikah sering memiliki kebiasaan buruk dalam pengelolaan keuangan pribadi, seperti misalnya: 1) selalu 
melakukan pengeluaran diluar rencana karena sikap konsumtif dan tidak tahan dengan pengaruh atau ajakan dari luar; 2) Selalu menggunakan prinsip tambal sulam yang artinya menggunakan biaya pengeluaran besok untuk hari ini, sehingga tidak konsisten dengan rencana keuangan pribadi yang dibuat; 3) Jika ada pemasukan diluar rencana, seringkali pemasukan tersebut langsung dihabiskan; 4) Seringkali jika mendapatkan dana dari pemasukan tetap (seperti gaji dan atau uang kiriman) 10 persen langsung dipakai untuk mentraktir teman atau melakukan aktivitas senang-senang; 5) Menggunakan tabungan atau dana investasi untuk pengeluaran tidak terduga yang tidak penting; 6) Berutang untuk hal-hal yang bukan menjadi kebutuhan, sehingga pada bulan berikutnya kebutuhan (ditambah utang) menjadi besar. Karyawan yang belum menikah memiliki sikap konsumtif yang tinggi jika dibandingkan dengan karyawan yang sudah berkeluarga. Yulianti dan Silvy (2013) menyatakan bahwa karyawan yang belum menikah banyak yang kurang memiliki pengetahuan akan pengelolaan keuangan, jika hal tersebut terjadi maka tidak dapat merencanakan dan mengendalikan penggunaan uangnya untuk mencapai tujuan hidup pribadi individu.

Adapapun rumusan masalah dalam penelitian ini adalah sebagai berikut:

1) Apakah financial literacy berpengaruh signifikan terhadap keputusan investasi individu?

2) Apakah jenis kelamin berpengaruh signifikan terhadap keputusan investasi individu? 
3) Apakah pendapatan berpengaruh signifikan terhadap keputusan investasi individu?

Menurut Tandelilin (2010) beberapa alasan seseorang melakukan investasi antara lain:

1) Untuk mendapatkan kehidupan yang lebih layak di masa mendatang. Seseorang yang bijaksana akan berpikir untuk meningkatkan taraf hidupnya dari waktu ke waktu atau setidaknya berusaha mempertahankan tingkat pendapatannya yang ada sekarang agar tidak berkurang di masa yang akan datang.

2) Mengurangi tekanan inflasi. Dengan melakukan investasi dalam pemilikan perusahaan atau objek lain, seseorang dapat menghindarkan diri dari risiko penurunan nilai kekayaan atau hak miliknya akibat pengaruh inflasi.

3) Dorongan untuk menghemat pajak Adanya kebijakan di beberapa negara yang bersifat mendorong tumbuhnya investasi di masyarakat melalui pemberian fasilitas perpajakan kepada masyarakat yang melakukan investasi pada bidang tertentu. Sedangkan dasar-dasar yang mendukung keputusan investasi adalah sebagai berikut:

a) Return, merupakan tingkat keuntungan investasi sebagai pengembalian atas dana yang telah diinvestasikan investor. Sedangkan return harapan investaso dari investasi yang dilakukannya merupakan kompensasi atas biaya kesempatan (opportunity cost) dan risiko penurunan daya beli akibat adanya pengaruh inflasi. Dalam koteks manajemen investasi perlu dibedakan antara return harapan (expected return) dengan return aktual 
(realized return). Return harapan merupakan tingkat return yang diharapkan akan diperoleh investor pada masa mendatang, sedangkan return aktual adalah return yang telah terjadi yang dihitung berdasarkan data historis.

b) Risiko, merupakan kemungkinan realisasi return aktual lebih rendah dari return minimum yang diharapkan. Dalam berinvestasi, investor mengharapkan return yang tinggi, namun besarnya risiko yang ditanggung juga harus diperhitungkan. Umumnya semakin besar risiko maka semakin besar return harapan.

Menurut Aminatuzzahra (2014) keputusan investasi ini didasarkan pada dua hal yaitu portofolio dan profitabilitas (keuntungan). Portofolio itu sendiri merupakan pembelian saham dengan momentum harga pada saat yang sama mengabaikan prinsip supply and demand yang sebenarnya sudah diketahui dalam financial behavior sebagai herd behavior (perilaku serentak).

Remund (2010) menjelaskan bahwa konsep dari financial literacy telah difokuskan pada lima domain. Domain-domian tersebut meliputi 1). pengetahuan dan konsep keuangan; 2). kemampuan untuk berkomunikasi tentang konsepkonsep keuangan; 3). bakat dalam mengelola keuangan pribadi; 4). keterampilan dalam membuat keputusan keuangan yang tepat; dan 5). keyakinan dalam perencanaan keuangan yang efektif untuk kebutuhan di masa depan.

Otoritas Jasa Keuangan (OJK) mendefinisikan bahwa literasi keuangan adalah rangkaian proses atau aktivitas untuk meningkatkan pengetahuan (knowledge), keterampilan (skill), dan keyakinan (confidence) konsumen dan 
masyarakat luas sehingga individu mampu mengelola keuangan pribadi lebih baik.

OJK menyatakan bahwa visi literasi keuangan adalah mewujudkan masyarakat Indonesia yang memiliki tingkat literasi keuangan yang tinggi sehingga masyarakat dapat memilih dan memanfaatkan produk dan jasa keuangan guna meningkatkan akses informasi. Misi dari literasi keuangan yaitu melakukan edukasi di bidang keuangan kepada masyarakat Indonesia agar dapat mengelola keuangan secara cerdas, dan meningkatkan akses informasi serta penggunaan produk dan jasa keuangan

Rita dan Kusumawati (2010) menyatakan faktor sosiodemografi terdiri dari jenis kelamin, usia, tingkat pendidikan, status perkawinan, pekerjaan, jabatan, dan pendapatan. Loix et al (2005) menemukan beberapa faktor demografi yaitu umur, jenis kelamin, besar keluarga, dan pekerjaan. Dalam penelitian ini faktor sosiodemografi yang akan digunakan adalah jenis kelamin dan pendapatan.

\section{METODE PENELITIAN}

\section{Jenis dan Sumber Data}

Data kuantitatif dalam penelitian ini meliputi skor atas jawaban responden melalui kuesioner yang terkumpul serta jumlah responden yang berpartisipasi. Data kualititatif dalam penelitian ini adalah hasil dugaan sementara hipotesis dan daftar pernyataan-pernyataan yang terdapat dalam kuesioner. Data primer diperoleh dari responden melalui penyebaran kuesioner. Data sekunder diperoleh 
dari berbagai sumber seperti buku, artikel, jurnal ilmiah sertas situs-situs resmi untuk menunjang proses penelitian.

\section{Variabel Penelitian}

Penelitian ini menggunakan variabel independen dan dependen. Variabel indenpenden terdiri dari financial literacy (X1) dan faktor sosiodemografi; jenis kelamin (X2) dan pendapatan (X3). Variabel dependen yaitu perilaku keputusan investasi individu (Y).

\section{Populasi dan Sampel}

Populasi dalam penelitian ini adalah seluruh karyawan yang belum menikah di Kota Denpasar, maka jumlah populasinya tidak bisa dihitung jumlahnya (infinate population).

\section{Metode Penentuan Sampel}

Teknik pengambilan sampel menggunakan non-probability sampling dengan pendekatan accidental sampling dimana pengambilan sampel didasarkan pada kenyataan bahwa responden kebetulan muncul. Jumlah sampel dalam penelitian ini sebanyak 83 orang dengan menggunakan Rumus Slovin sebagai berikut:

$\mathrm{n}=\frac{N}{1+N a^{2}}$

keterangan:

$\mathrm{n}$ : jumlah sampel yang digunakan

$\mathrm{N}$ : besar populasi

a : tingkat kesalahan yang digunakan 
Maka, $n=\frac{105}{1+105(0,05)^{2}}=83,16$ dibulatkan menjadi 83. Jumlah tersebut memenuhi syarat kriteria sampel menurut Sekaran (2003) yang mengatakan bahwa pada penelitian survey jumlah sampel yang digunakan lebih dari 30 responden dan kurang dari 500 responden sudah memadai untuk penelitian secara umum.

\section{Metode Pengumpulan Data}

Metode pengumpulan data menggunakan kuesioner yang disebar pada responden sesuai kriteria di Kota Denpasar. Para responden diminta untuk mengisi lengkap kuesioner yang diberikan. Kuesioner yang diberikan berisi tentang pernyataan-pernyataan untuk variabel financial literacy (X1), faktor sosiodemografi (X2) serta penyataan-pernyataan untuk variabel perilaku keputusan investasi individu (Y).

\section{Teknik Analisis Data}

Penelitian ini menggunakan metode statistik karena proses pengumpulan data, penarikan kesimpulan dan pembuatan keputusan dilakukan secara sistematis. Selanjutnya, fungsi statistik yang digunakan dalam penelitian ini adalah analisis deskriptif. Untuk menguji hasil kuesioner menggunakan uji validitas dan uji reliabilitas. Untuk menguji model regresi menggunakan uji asumsi klasik. Untuk menguji hipotesis menggunakan uji $\mathrm{F}$ (simultan), teknik analisis regresi linier berganda dan uji beda (Mann Whitney). 


\section{HASIL DAN PEMBAHASAN}

\section{Karakteristik Responden}

Berdasarkan jenis kelamin, responden didominasi oleh perempuan sebanyak $63,9 \%$, sedangkan sisanya laki-laki. Hal ini menunjukkan bahwa sebagian besar responden yang ikut berpartisipasi dalam penelitian ini adalah perempuan. Berdasarkan tingkat pendapatan, mayoritas responden memiliki tingkat pendapatan yang tinggi yaitu lebih dari Rp 3.000.000.

Tabel 1.

Karakteristik Responden

\begin{tabular}{ccccc}
\hline No. & Variabel & Klasifikasi & $\begin{array}{c}\text { Jumlah } \\
\text { (Orang) }\end{array}$ & Persentase \\
\hline \multirow{2}{*}{1.} & Jenis Kelamin & Laki-Laki & 30 & $36,1 \%$ \\
& Jumlah & Perempuan & 53 & $63,9 \%$ \\
& Rendah & $\mathbf{8 3}$ & $\mathbf{1 0 0 \%}$ \\
& & $1.000 .000-$ & 19 & $22,9 \%$ \\
2. & Tingkat & Sedang & & \\
& Pendapatan & $(>2.000 .000-$ & 20 & $24,1 \%$ \\
& & $3.000 .000)$ & & $53 \%$ \\
& & Tinggi & 44 & $\mathbf{1 0 0 \%}$ \\
\hline
\end{tabular}

Sumber: Data yang diolah, 2017

\section{Hasil Uji Validitas dan Reliabilitas}

Seluruh item pernyataan menunjukkan signifikansi dari masing-masing butir pernyataan terhadap total skor butir pernyataan $<0,05$ atau dapat dilihat dari nilai $T_{\text {hitung }}>T_{\text {tabel }}(0,2133)$ pada nilai siginifikansi 0,05 , maka dapat dijelaskan bahwa seluruh indikator konstruk dalam penelitian ini adalah valid, sehingga dapat digunakan sebagai instrumen penelitian. 
Uji reliabilitas menggunakan rumus Cronbach Alpha dengan taraf signifikansi 0,05 . Instrumen penelitian dapat dikatakan reliabel jika nilai alpha lebih besar dari 0,06 .

Tabel 2.

Hasil Uji Validitas

\begin{tabular}{|c|c|c|c|}
\hline Indikator & Simbol & $T_{\text {hitung }}$ & Signifikansi \\
\hline $\begin{array}{l}\text { Pengetahuan dasar mengenai keuangan pribadi } \\
\text { (basic personal finance) }\end{array}$ & $\mathrm{X} 1.1$ & 0,905 & 0,000 \\
\hline $\begin{array}{l}\begin{array}{l}\text { Pengetahuan } \\
\text { management) }\end{array} \quad \text { manajemen } \quad \text { uang } \quad \text { (money } \\
\end{array}$ & $\mathrm{X} 1.2$ & 0,906 & 0,000 \\
\hline $\begin{array}{l}\text { Pengetahuan manajemen kredit dan utang(credit } \\
\text { and debt management) }\end{array}$ & X1.3 & 0,825 & 0,000 \\
\hline $\begin{array}{l}\text { Pengetahuan tabungan dan investasi (saving and } \\
\text { investment) }\end{array}$ & X1.4 & 0,512 & 0,000 \\
\hline $\begin{array}{l}\text { Pengetahuan manajemen risiko keuangan (risk } \\
\text { financial management) }\end{array}$ & $\mathrm{X} 1.5$ & 0,795 & 0,000 \\
\hline $\begin{array}{l}\text { Mampu memperhitungkan keamanan dan risiko } \\
\text { (keamanan dalam suatu investasi berarti kerugian } \\
\text { minimal) }\end{array}$ & Y1.1 & 0,772 & 0,000 \\
\hline $\begin{array}{l}\text { Mampu memprediksi komponen faktor risiko } \\
\text { (komponen faktor risiko yang berkaitan dengan } \\
\text { investasi khusus berubah dari waktu ke waktu) }\end{array}$ & Y1.2 & 0,898 & 0,000 \\
\hline $\begin{array}{l}\text { Mampu meramalkan pendapatan investasi } \\
\text { (pendapatan dalam bentuk tunai dan bersifat pasti) }\end{array}$ & Y1.3 & 0,815 & 0,000 \\
\hline $\begin{array}{l}\text { Dapat memahami pertumbuhan investasi } \\
\text { (peningkatan dalam nilai) }\end{array}$ & Y1.4 & 0,914 & 0,000 \\
\hline $\begin{array}{l}\text { Dapat menganalisa tingkat likuiditas (tinggi atau } \\
\text { rendah) }\end{array}$ & Y1.5 & 0,834 & 0,000 \\
\hline
\end{tabular}

Sumber: Data yang diolah, 2017

Tabel 3.

Hasil Uji Reliabilitas

\begin{tabular}{lcc}
\hline \multicolumn{1}{c}{ Variabel } & Simbol & Cronbach Alpha \\
\hline Financial Literacy & $\mathrm{X}$ & 0,857 \\
Perilaku Keputusan Investasi Individu & $\mathrm{Y}$ & 0,900 \\
\hline
\end{tabular}

Sumber: Data diolah, 2017

\section{Hasil Uji Asumsi Klasik}

Hasil uji normalitas pada variabel perilaku keputusan investasi individu (Y) menujukkan angka signifikansi sebesar 0,954 yang berarti bahwa 0,954>0,05 
sehingga dapat dinyatakan bahwa data dari variabel perilaku keputusan investasi individu pada 83 sampel berdistribusi normal atau memenuhi persyaratan uji normalitas. Pada hasil uji multikolinieritas nilai tolerance masing-masing model menunjukkan nilai $>0,1$ dan nilai VIF masing-masing model menunjukkan nilai < 10 sehingga dapat dikatakan bahwa model regresi dalam penelitian ini adalah bebas multikolinieritas. Pada uji heteroskedastisitas pmenunjukkan hasil uji heteroskedastisitas pada variabel financial literacy sebesar 0,159, variabel jenis kelamin sebesar 0,525, dan pendapatan sebesar 0,549. Nilai signifikansi seluruh model regresi menunjukkan nilai $>0,05$, maka dapat dikatakan model regresi dalam penelitian ini tidak terjadi heteroskedastisitas.

Tabel 4.

Hasil Uji Asumsi Klasik

\begin{tabular}{lll}
\hline \multicolumn{1}{c}{ Uji Asumsi Klasik } & \multicolumn{1}{c}{ Hasil Uji } & \multicolumn{1}{c}{ Keterangan } \\
\hline Uji Normalitas & $\mathrm{p}(0,954)>0,05$ & Berdistribusi normal \\
Uji Multikolinearitas & Tolerance $(0,457) ;(0,939) ;$ & \\
& $(0,562)>0,1$ & Tidak ada multikolinearitas \\
& VIF $(2,188) ;(1,065) ;(2,163)$ & \\
Uji Heteroskedastisitas & $<10$ & Tidak terjadi \\
& $\mathrm{p}(0,159) ;(0,525) ;(0,549)$ & heteroskedastisitas \\
\hline
\end{tabular}

\section{Hasil Uji Hipotesis}

Untuk menguji pengaruh variabel independen yaitu financial literacy, jenis kelamin dan pendapatan terhadap variabel dependen yaitu perilaku keputusan investasi individu menggunakan analisis regresi linier berganda.

Tabel 5.

Analisis Regresi Linier Berganda

\begin{tabular}{lccc}
\hline \multicolumn{1}{c}{ Variabel } & Koefisien & Nilai t & Signifikansi \\
\hline (constant) & $-4,499$ & $-3,517$ & 0,001 \\
Financial Literacy & 1.078 & 12.693 & 0,000 \\
Jenis Kelamin & 1.308 & 2.917 & 0,005 \\
Pendapatan & -.633 & -1.685 & 0,096 \\
F : 107,803 & & & 0,000 \\
\hline
\end{tabular}


Dari Tabel 5. Diperoleh persamaan regresi sebagai berikut:

$$
Y=-4,499+1,078 X_{1}+1,308 X_{2}-0,633 X_{3}
$$

Berdasarkan persamaan regresi diatas, maka dapat dianalisis sebagai berikut:

a) Nilai dari konstanta pada hasil uji regresi menunjukkan nilai $-4,499$, apabila nilai konstantanya negatif bisa diabaikan selama model regresi sudah memenuhi asumsi (hasil uji asumsi klasik). Maka nilai konstanta diatas tidak perlu diinterpretasikan.

b) Koefisien regresi financial literacy (X1) menunjukkan nilai sebesar 1,078 ini berarti menunjukkan arah pengaruh antara financial literacy (X1) terhadap perilaku keputusan investasi individu (Y) adalah signifikan positif dengan nilai signifikasinya 0,000 lebih kecil dari 0,05 . Hal ini berarti pengaruh variabel financial literacy berbanding lurus dengan perilaku keputusan investasi individu artinya semakin tinggi financial literacy seseorang, maka semakin baik perilaku keputusan investasi individunya.

c) Koefisien regresi jenis kelamin (X2) sebesar 1,308 menunjukkan arah pengaruh antara jenis kelamin terhadap perilaku keputusan investasi individu adalah signifikan positif dengan nilai signifikasinya 0,005 lebih kecil dari 0,05. Hal ini berarti pengaruh variabel jenis kelamin berbanding lurus dengan perilaku keputusan investasi individu artinya adanya pengaruh antara jenis kelamin dengan perilaku investasi individu.

d) Koefisien regresi pendapatan (X3) sebesar -0,633 menunjukkan arah pengaruh antara pendapatan terhadap perilaku keputusan investasi individu adalah signfikan negatif dengan nilai signifikansinya 0,096 lebih besar dari 
0,05 . Hal ini berarti pengaruh variabel pendapatan berbanding terbalik dengan perilaku keputusan individu dengan signifikansi yang lebih besar dari 0,05 artinya tidak ada pengaruh antara pendapatan dengan perilaku investasi.

\section{Hasil Uji F (Simultan)}

Berdasarkan hasil uji $\mathrm{F}$ (simultan) menunjukkan bahwa nilai $\mathrm{F}$ sebesar 107,803 dengan signifikan 0,000 yang nilainya kurang dari 0,05 maka keputusannya $H_{O}$ ditolak sehingga dapat dikatakan bahwa adanya pengaruh financial literacy dan faktor sosiodemografi secara simultan terhadap perilaku keputusan investasi individu.

\section{Hasil Uji Beda (Mann Whitney)}

Rata-rata antara perempuan dan laki-laki terhadap perilaku keputusan investasi adalah berbeda. Pada perempuan menunjukkan rata-rata sebesar 48,04, angka tersebut lebih besar dibandingkan dengan rata-rata yang dimiliki oleh lakilaki yaitu sebesar 31,33. Pada tabel 5.13 nilai signifikansinya sebesar 0,002 yaitu lebih kecil daripada 0,05 maka dapat dikatakan bahwa adanya perbedaan jenis kelamin antara laki-laki dan perempuan dalam perilaku keputusan investasi individu. Berdasarkan hasil nilai rata-rata dalam penelitian ini dinyatakan bahwa perempuan memiliku perilaku keputusan investasi individu lebih tinggi dibandingkan dengan laki-laki.

Tabel 6.

Hasil Uji Beda (Mann Whitney)

\begin{tabular}{cccc}
\hline & Jenis Kelamin & N & Mean Rank \\
\hline \multirow{3}{*}{ Keputusan Investasi } & Laki-Laki & 30 & 31,33 \\
& Perempuan & 53 & 48,04
\end{tabular}


Ni Made Dwiyana Rasuma Putri dan Henny Rahyuda. Pengaruh Tingkat Financial ...

Pengaruh Tingkat Financial Literacy Terhadap Perilaku Keputusan Investasi Individu

Hasil uji analisis regresi linier berganda menunjukkan koefisien regresi financial literacy (X1) menunjukkan nilai sebesar 1,078 ini berarti menunjukkan arah pengaruh antara financial literacy (X1) terhadap perilaku keputusan investasi individu (Y) adalah signifikan positif dengan nilai signifikasinya 0,000 lebih kecil dari 0,05. Pengaruh variabel financial literacy berbanding lurus dengan perilaku keputusan investasi individu artinya semakin tinggi financial literacy seseorang, maka semakin baik perilaku keputusan investasi individunya.

Hal ini mendukung hasil penelitian yang dilakukan oleh Xiao et al., (2006) dan Robb Cliff (2011) yang mengemukkan seseorang dengan tingkat pengetahuan keuangan (financial literacy) yang baik maka perilaku keuangannya cenderung kearah yang lebih baik dibandingkan dengan seseorang yang tingkat pengetahuan keuangan yang lebih rendah. Kemudian hasil penelitian yang dilakukan oleh Lusardi dan Mitchell (2007) mengatakan bahwa tingkat financial literacy yang memadai akan membuat seseorang melakukan perencanaan termasuk perencanaan antisipasi masa pensiun dengan investasi sejak usia produktif.

\section{Pengaruh Jenis Kelamin Terhadap Perilaku Keputusan Investasi Individu}

Hasil uji regresi linier berganda pada menunjukkan bahwa koefisien regresi jenis kelamin (X2) sebesar 1,308 menunjukkan arah pengaruh antara jenis kelamin terhadap perilaku keputusan investasi individu adalah signifikan positif dengan nilai signifikasinya 0,005 lebih kecil dari 0,05. Dalam hal ini pengaruh variabel jenis kelamin berbanding lurus dengan perilaku keputusan investasi 
individu artinya adanya pengaruh antara jenis kelamin dengan perilaku investasi individu.

Hasil uji beda (Mann Whitney) pada yang menunjukkan bahwa secara statistik ada perbedaan antara perempuan dan laki-laki terhadap perilaku keputusan investasi individu. Perempuan memiliki perilaku keputusan investasi individu yang lebih tinggi dibandingkan dengan laki-laki.

Hasil penelitian tersebut didukung oleh penelitian yang dilakukan oleh Hayhoe et al, (2000) yang mengatakan bahwa perbedaan gender berpengaruh signifikan dalam perilaku keuangan termasuk keputusan dalam investasi individu. Loix et al, (2005) yang menemukan perempuan lebih berhati-hati menggunakan uangnya untuk hal yang tidak bermanfaat dibandingkan dengan laki-laki yang lebih sering membelanjakan uangnya untuk hal yang tidak berguna yang berarti bahwa seorang perempuan lebih bersifat bijaksana dalam menggunakan uangnya untuk menabung atau berinvestasi dibandingkan untuk konsumsi.

\section{Pengaruh Pendapatan Terhadap Perilaku Keputusan Investasi Individu}

Hasil uji regresi linier berganda pada menunjukkan bahwa koefisien regresi pendapatan (X3) sebesar -0,633 menunjukkan arah pengaruh antara pendapatan terhadap perilaku keputusan investasi individu adalah signfikan negatif dengan nilai signifikansinya 0,096 lebih besar dari 0,05. Dalam hal ini ini pengaruh variabel pendapatan berbanding terbalik dengan perilaku keputusan individu dengan signifikansi yang lebih besar dari 0,05 artinya tidak ada pengaruh antara pendapatan dengan perilaku keputusan investasi individu. 
Hasil penelitian ini didukung penelitian yang dilakukan OJK (2013) menyatakan bahwa kurangnya pengetahuan dan pencarian informasi mengenai investasi pada lembaga keuangan apakah itu bank atau asuransi dan kurang pahamnya mengenai manfaat tabungan atau asuransi tersebut membuat masyarakat enggan untuk melakukan investasi. Zebua (2001) menyatakan bahwa semakin banyak seseorang memiliki uang, maka semakin meningkat pula keinginannya untuk berbelanja.

Hal yang sama pada penelitian Rita dan Kusumawati (2010) menyatakan bahwa semakin tinggi pendapatan yang dimiliki seseorang, semakin besar keinginan seseorang untuk membeli apa yang diinginkan melebihi apa yang dibutuhkan, seseorang yang seperti ini kurang paham dengan manfaat menabung atau berinvestasi untuk masa depan.

\section{SIMPULAN DAN SARAN}

Berdasarkan hasil pembahasan penelitian yang telah dilakukan, maka dapat disimpulkan bahwa:

1) Financial literacy berpengaruh signifikan positif terhadap perilaku keputusan investasi individu. Artinya, semakin tinggi tingkat financial literacy, maka semakin baik perilaku keputusan investasi individu.

2) Jenis kelamin berpengaruh signifikan terhadap perilaku keputusan investasi individu. Artinya, adanya perbedaan signifikan antara perempuan dan laki-laki dalam perilaku keputusan investasi individu. 
3) Pendapatan tidak berpengaruh signifikan terhadap perilaku keputusan inventasi. Artinya, tingkat pendapatan seseorang tidak menjadi tolak ukur untuk melakukan sebuah keputusan investasi individu.

\section{Saran}

1) Masyarakat perlu menyadari bahwa pentingnya financial literacy dalam pengelolaan dana karena faktor ini merupakan faktor utama di dalam melakukan sebuah investasi dimana akan bermanfaat ketika di masa mendatang. Diharapkan kepada lembaga jasa keuangan agar lebih melakukan sosioalisasi tentang financial literacy kepada masyarakat.

2) Pencarian informasi tentang melakukan sebuah investasi sangat penting untuk diperoleh karena masyarakat harus paham komponen-komponen apa saja yang terdapat pada sebuah produk investasi agar nantinya tidak mudah tertipu dan tergiur dengan produk investasi yang ditawarkan oleh lembaga jasa keuangan.

3) Tingkat financial literacy yang baik akan mengarah pada masyarakat yang sadar untuk melakukan investasi maka diharapkan kepada lembaga jasa keuangan agar melakukan pengembangan produk-produk investasi agar masyarakat banyak memiliki pilihan produk dalam melakukan investasi.

4) Peneltian dimasa datang diharapkan mampu untuk mengembangkan empiris dan teori mengenai perilaku terkait bidang ilmu manajemen keuangan. Variabel yang disarankan untuk penelitian di masa depan adalah kepuasan keuangan (financial satisfaction) dan perilaku keuangan (financial behavior) dalam perilaku keputusan investasi individu. 


\section{IMPLIKASI PENELITIAN}

\section{Implikasi Teoritis}

Hasil penelitian ini telah menunjukkan bagaimana pengaruh antara tingkat financial literacy dan faktor sosiodemografi terhadap perilaku keputusan investasi individu. Berdasarkan temuan tersebut, maka hasil penelitian ini mampu memperkaya konsep financial literacy yang dikemukakan oleh beberapa ahli terdahulu serta mendukung studi-studi empiris terkait pengetahuan manajemen keuangan yang menentukan perilaku keputusan investasi pada individu.

\section{Implikasi Praktis}

Berdasarkan hasil penelitian tersebut ada implikasi praktis yang dihasilkan. Berdasarkan persamaan regresi linier berganda variabel financial literacy memiliki pengaruh paling besar dalam menentukan perilaku keputusan investasi individu dibandingkan dengan faktor sosiodemografi. Hal ini menjelaskan bahwa pengetahuan seseorang tentang mengelola keuangan pribadinya menjadi faktor utama dalam menentukan keputusan sebuah investasi.

Informasi dan sosialisasi merupakan sumber dari pengetahuan pengelolaan keuangan. Pentingnya hal ini merupakan tugas yang besar bagi lembaga keuangan kepada masyarakat terlebih masyarakat yang telah memiliki pendapatan tetap berupa gaji per bulannya. Financial literacy yang tinggi bermanfaat agar terhindar dari kesulitan finansial contohnya adalah melakukan perencanaan keuangan. Seseorang yang memiliki perencanaan keuangan adalah suatu hal yang penting. Dana yang disisihkan dapat digunakan sebagai dana cadangan yang sewaktuwaktu dapat digunakan dalam kondisi darurat atau untuk berinvestasi. 
Pengetahuan tentang pengelolaan keuangan pribadi penting dilakukan ketika usia produktif agar nantinya dapat selalu memenuhi kebutuhan akan hidup.

\section{Keterbatasan Penelitian}

1) Penelitian ini hanya menggunakan responden karyawan yang belum menikah di Kota Denpasar, sehingga penting untuk penelitian dimasa mendatang melengkapi dan memperkaya studi empiris terkait topik dengan menggunakan responden lain, disarankan seperti responden usia remaja karena financial literacy dan perilaku investasi penting dimiliki pada usia sedini mungkin. Pada penelitian selanjutnya diharapkan juga peneliti mampu memberikan informasi mengenai perbedaan perilaku keputusan investasi individu berdasarkan jenis pekerjaannya seperti PNS atau Swasta.

2) Pada variabel faktor sosiodemografi pada penelitian ini hanya menggunakan dua faktor saja yaitu jenis kelamin dan pendapatan karena data yang diperoleh di lapangan variabel usia dan tingkat pendidikan bersifat homegen dengan demikian penelitian dimasa mendatang menembah lagi faktor-faktor sosiodemografi lainnya seperti usia, tingkat pendidikan yang bersifat heterogen demi hasil penelitian yang lebih beragam dan padat serta pada variabel pendapatan karena pada variabel pendapatan masih ada inkonstannya hasil penelitian maka perlu untuk diteliti lagi.

3) Variabel pada penelitian ini hanya menggunakan financial literacy dalam bidang ilmu manajemen keuangan dalam konteks perilaku. Masih banyak variabel-variabel lain yang perlu diteliti kembali dimasa datang untuk menambahkan empiris dan teori mengenai perilaku terkait ilmu manajemen 
keuangan. Variabel yang disarankan untuk penelitian di masa depan adalah kepuasan keuangan (financial satisfaction) dan perilaku keuangan (financial behavior) dalam perilaku keputusan investasi individu.

\section{REFERENSI}

Aminatuzzahra. 2014. Persepsi Pengaruh Pengetahuan Keuangan, Sikap Keuangan, Sosial Demografi Terhadap Perilaku Keuangan dalam Pengambilan Keputusan Investasi Inidividu. Journal Financial Behavior, July 2014.

Chen, H. \& Volpe, R. P. 1998. "An analysis of personal financial literacy among college students”, Financial services review, 7(2): 107-128.

Chen, H., \& Volpe, R. P. 2002. Gender differences in personal financial literacy among college students. Financial Services Review, 11, 289-307.

Haming, Murdifin.,\& Basamalah Salim. 2010. Studi Kelayakan Investasi Proyek dan Bisnis. Jakarta: Bumi Aksara.

Hayhoe, C. R., Leach, L. J., Turner, P. R., Bruin, M. J., \& Lawrence, F. C. (2000). Differences in spending habits and credit use of college students. Journal of Consumer Affairs, 34(1), 113-133.

Hilgert, M. A., Hogarth, J. M., \& Beverly, S. G. 2003. Household financial management: The connection between knowledge and behavior. Household Saving: Does Financial Education Work? Social Security Bulletin, 72(2), 309-322.

Hutahaean, M. 2011, October 9. Have you heard about psychology? Retrieved from http://meltri-elia.blogspot.com/2011/10/konsep-konsumsikonsumen-konsumtif.html

Ibrahim, M.E., Alqaydi F.R. 2013. Financial Literacy, Personal Financial Attitude, and Forms of Personal Debt among Residents of the UAE. International Jpurnal of Economics and Finance, Vol. 5, No. 7; 2013

Imawati, et al, I., Susilaningsih, \& Ivada, E. 2013. Pengaruh financial literacy terhadap perilaku konsumtif remaja pada program IPS SMA Negeri 1 Surakarta tahun ajaran 2012/2013. Jupe UNS, 2(1), 48-58

John, G. E., Park, J.-Y., \& Joo, S.-H. 2009. Explaining Financial Management Behavior for Koreans Living in the United States. The Journal of Consumer Affairs , 80. 
Loix, E., Pepermans, R., \& Hove, L. V. 2005. Who's afraid of the cashless society? : Belgia survey evidence. Preliminary Journal.

Lusardi, A., \& Mitchell, O. S. 2007. Baby Boomer retirement security: The roles of planning, financial literacy, and housing wealth. Journal of Monetary Economics, 54, 205-224

Lusardi, A., Mitchell, O. \& Curto, V. 2008. Financial Literacy among theYoung. Working Paper of Michigan Retirement Research Center, University of Michigan.

Lusardi, A. \& Tufano, P. 2009. Debt literacy, financial experiences, and overindebtedness. NBER Working Paper No. 14808.

Lusardi, A., Mitchell, O. S., \& Curto, V. 2010. Financial literacy among the young. The Journal of Consumer Affairs, 44(2), 358-380. http://dx.doi.org/10.1111/j.1745-6606.2010.01173.x

Lusardi, A. \& Mitchell, O. (2011). Financial Literacy around the World: An Overview. Journal of Pension Economics and Finance: University of Pennyslavania. (online)(https://doi.org/10.1017/S1474747211000448) pp 497-509

Mandell, L. (2004). Personal Financial Survey of High School Seniors. Washington, DC: The Jumpstart Coalition for Personal Financial Literacy

Marianne A. Hilgert. 2003. Household Financial Management: The Connection between Knowledge and Behavior. Federal Reserve Bulletin

Masassya, E. G. 2006. Arsitektur Keuangan Pekerja Profesi. Kompas, Edisi 7 Agustus

Remund, D. L. 2010. Financial literacy explicated: The case for a clear definition in an increasingly complex economy. The Journal of Consumer Affairs, 44(2), 276-295. http://dx.doi.org/10.1111/j.1745$\underline{6606.2010 .01169 .}$.

Rita, M. R. \& Kusumawati, R. 2010. Pengaruh variabel sosio demografi dan karakteristik finansial terhadap sikap, norma subyektif dan control perilaku menggunakan kartu kredit: Studi pada pegawai di UKSW Salatiga. 109-128.

Robb, C. and Deanna L. S., 2009 Effect Of Personal Financial Knowledge On College Student's Credit Card Behavior, Jurnal Of Financial And Planing, Vol.20. 
Robb, C. A. and James, R. N. 2009. Associations between individual characteristics and financial knowledge among college students. Journal of Personal Finance, 8, 170-184.

Robb, C. A., \& Woodyard, A. S. (2011). finanacial knowledge and best practice behaviour. Journal of financial Counseling and planning Volume 22 Issue 1.

Sekaran, Uma. 2003.Methods for Business - A Skill-Building Approach. 4th EdResearch John Wiley \& Sons, Inc, New York

Setiawan, Eru., Sugeng Wahyudi., Wisnu Warmadi. 2016. Pengaruh Sosial Demografi, Pengetahuan Keuangan, dan Sikap Keuangan Terhadap Perilaku Investasi Keuangan Individu. Tesis. Program Magister Manajemen Universitas Diponogoro.

Tandelilin, Edudardus. 2010. Portofolio dan Investas, Teori dan Aplikasi. Edisi Pertama. Yogyakarta, Penerbit Kanisius.

Volpe, R. B., Chen, H., \& Liu, S. 2006. An analysis of the importance of personal finance topics and the level of knowledge possessed by working adults. Financial Services Review, 15(1), 81-99.

Xiao, J. J., Sorhaindo, B., \& Garman, E. T. 2006. Financial behaviour of consumer in credit counseling. International Journal of Consumer Studies , 108-121

Yulianti, Norma dan Silvy Meliza. 2013. Sikap Pengelola Keuangan Dan Perilaku Perencanaan Investasi Keluarga Di Surabaya. Journal of Business and Banking. (online),

(https://journal.perbanas.ac.id/index.php/jbb/article/view/254) Vol. 3

No. 1

Zebua, A.S \& Nurdjayadi, R.D. 2001. Hubungan antara Konformitas dan Konsep Diri dengan Perilaku Konsumtif pada Remaja Putri. Jurnal Phronesis .3. (6). 72-82 